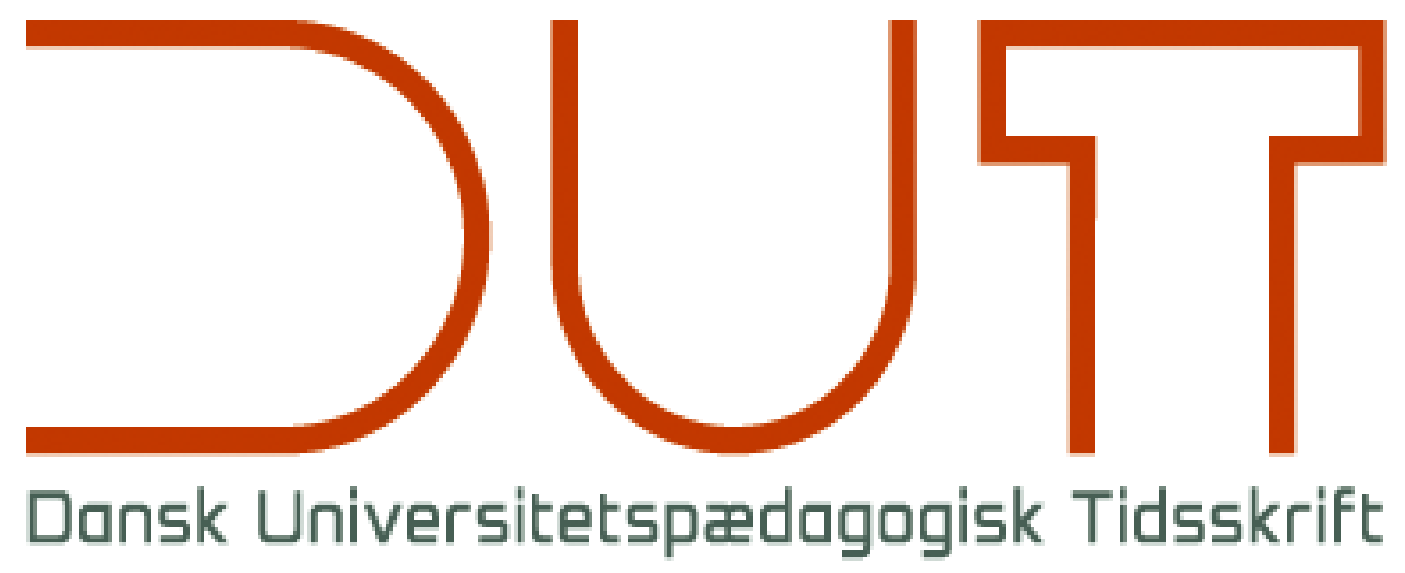

Tema

Forfattere

Sidetal

Udgivet af

URL

Fra data til beslutninger

Årgang 14 nr. 26 / 2019

Takeaway Teaching - A design for redesign

Hanne Balsby Thingholm, Anders Hjortskov Larsen

103-114

Dansk Universitetspædagogisk Netværk, DUN

> http://dun-net.dk/

Betingelser for

brug af denne

artikel

(C) Copyright
Denne artikel er omfattet af ophavsretsloven, og der må citeres fra den. Følgende betingelser skal dog være opfyldt:

- Citatet skal være i overensstemmelse med "god skik"

- Der må kun citeres „i det omfang, som betinges af formålet“

- Ophavsmanden til teksten skal krediteres, og kilden skal angives ift. ovenstående bibliografiske oplysninger.

DUT og artiklens forfatter 


\title{
Takeaway Teaching - A design for redesign
}

\author{
Hanne Balsby Thingholm ${ }^{1, a}$, Anders Hjortskov Larsen ${ }^{b}$ \\ ${ }^{a, b}$ Center for undervisningsudvikling og digitale medier, Aarhus Universitet
}

Practice paper, peer-reviewed

\begin{abstract}
This paper introduces a new teaching design called Takeaway Teaching. The design consists of pre-designed generic themes and activities that support the development of study strategies in higher education. These themes and activities are easily redesigned by the teacher and integrated into the academic curriculum. The purpose of the design is twofold. It supports the didactic reflection and development of the teacher and the development of the students' study competence. This paper presents the theoretical framework of the design, based on a theoretical approach of metacognition and second-order teaching and learning, and an example of a redesign of one of the generic themes; Literature Search.
\end{abstract}

\section{Takeaway teaching - A design for redesign}

This paper is a practical contribution to university teaching and presents a new teaching design called Takeaway Teaching. The purpose of this design is, by means of pre-designed generic themes, to make it easy for university teachers to integrate activities into the academic curriculum and explicitly teach study strategies. This design is an alternative to generic courses in study skills. We think that an alternative to generic study courses is important for two reasons. Students who need help to develop study competence are often not motivated to sign up and attend the courses. Furthermore, generic courses often lead to a transfer problem for the students and they find it hard to integrate the skills they have learned into their academic discipline.

The Takeaway Teaching design and its theoretical framework have a strong student-oriented perspective, and support the idea that teachers may teach students how to actively learn course content, rather than the idea that the primary objective is for teachers to teach content. This perspective includes a focus on how students study, and suggests that study strategies be addressed as an integral part of the curriculum, rather than as something that the students must figure out on their own. The design consists of the following themes: Academic Reading, Academic Writing, Academic Oral Presentation, Peer-feedback, Group Work, MA Preparation, BA Preparation, Literature Search and a Project-oriented theme. Currently the design consists of 13 pre-designed mini-plans or scripts, which are available from the digital resource AU Educate: http://educate.au.dk/forloeb/. The themes of the Takeaway Teaching design inspire university teachers to implement various study strategies into their curriculum and teaching. The themes and their activities may be implemented directly or redesigned by the teacher in order to match the students and the subject area. When redesigning the theme, the teacher may choose to remove and add elements and activities to it, in order to qualify the students' achievements with respect to a given academic curriculum. In this way,

\footnotetext{
${ }^{1}$ Contact: hbt@tdm.au.dk
} 
the design of Takeaway Teaching is flexible, and aims to develop teaching competence as well as study competence.

\section{Theoretical framework of Takeaway Teaching}

The theoretical framework of the Takeaway Teaching design is inspired by theories of system theory and metacognition. This combination emphasizes communication and suggests directing didactic attention towards teaching students how to study. In the following sections, we present the theoretical concepts underlying the Takeaway Teaching design: metacognition and second-order teaching. When combining these concepts, it becomes meaningful to talk about metacommunication.

\section{Metacognition in teaching and learning}

Theories about metacognition have been related to teaching and learning since the late 1970s, when John Flavell defined metacognition as: "knowledge and cognition about cognitive phenomena" (Flavell, 1979 p. 906), or put more straightforwardly, "thinking about thinking." According to Flavell, metacognitive knowledge has three aspects: knowledge about yourself as a person, knowledge about the task, and knowledge about the strategies appropriate for solving the task (Flavell, 1979 p. 907). Since Flavell's definition of metacognition, the concept has been defined and explored in various ways. However, the literature for the field of metacognition reflects a consensus that distinguishes between two elements: metacognitive knowledge and metacognitive control. In order to develop metacognitive knowledge and control, three dimensions of knowledge are essential:

1. Declarative knowledge about what you know about the task in which you are engaged. This relates to the content dimension.

2. Procedural knowledge about how you can solve the task, and about which strategies to use. This relates to procedure and method.

3. Conditional knowledge about why and when the task is being done. This relates to purpose, state and context.

(Schraw, Crippen, \& Hartley; 2006 Kuhn \& Dean, 2004).

According to Harrison and Vallin (2017), metacognition is valuable in various ways related to students' learning processes. From research on collaborative learning, we know that metacognition is important for collective content learning, from motivation research we know that metacognition is important for successful learning strategies, and from literature on critical thinking, we know that metacognition is often regarded as the basis for critical thinking. According to Coutinho (2008), students improve their learning skills when they are trained in metacognitive skills, and metacognition is an important predictor for academic achievement. Having metacognitive skills makes it easier to apply one's knowledge in different contexts (Pintrich, 2002; Veenman, 2015), and to engage in creative problem-solving (Hargrove \& Nietfeld, 2015). According to Frenkel (2014), metacognitive skills are not genetically determined. Some students may have stronger metacognitive skills than others, but everybody can learn metacognitive skills to a certain extent. We agree with the description of metacognition as a "sleeping potential" (Frenkel, 2014). 


\section{Second-order teaching}

From this perspective, teaching students how to study not only includes metacognitive orientation, it also identifies the importance of second-order teaching. Second-order teaching is a theoretical concept that draws on Luhmann's understanding of second-order observation and Bateson's understanding of context learning. The theoretical analysis of the concept of second-order teaching is articulated by Thingholm and Keiding (2018). In the following sections, we extract the main points of this work by explaining the concepts of second-order observation and context learning. We also describe how, from this perspective, reflection on the implications for teaching emerges as two-sided, considering both the teaching and learning processes.

\section{Second-order observation}

According to the German sociologist Niklas Luhmann, an observation is always an interpretation. Consequently, different observers or systems will make different observations or interpretations of what they see - a first-order observation. A second-order observation is a certain kind of observation or interpretation that observes the first observation, or in other words, observes how something has been observed (Luhmann, 2007, p. 143). Second-order observations observe the immediate, i.e. first, observation. An example is the teacher who finds the students skilful and hardworking. This would be the teacher's first observation, an observation of what, of skilful students. When the teachers observe their first observation, it becomes possible to understand how they have made distinctions in the first observation. Does the teacher compare the students to last year's students? Does the teacher refer to a test or an exam? Has the teacher been observing the students for a long time, or just one week? (Thingholm and Keiding, 2018).

Second-order observations relate to how an observation or interpretation has been observed or interpreted. Second-order observations aim to understand the distinctions behind the first observation. According to Luhmann, any observation or interpretation is based on a distinction and this distinction is essential to understanding any given question (Luhmann, 2007, p. 144). Therefore, second-order observations are crucial to the teacher's didactic reflections, in order to plan, conduct and evaluate teaching and learning.

In line with second-order observation, which is the observation that observes an observation, second-order teaching is teaching that observes teaching. In order to understand how this is possible, we turn to Luhmann's understanding of teaching and learning. Teaching and learning are closely connected, but at the same time, they are two very different concepts or systems. Teaching is a social system maintained by communication. Teaching is the interaction that takes place when teachers and students engage in a dialogue. On the other hand, learning is an individual endeavour and refers to the psychological system that is maintained by thoughts and consciousness. Learning occurs in the mind of each student (and teacher), whereas teaching is a joint effort. When learning takes place in the students' minds, it is not possible for the teacher to directly observe the students' learning processes; the teacher cannot access the students' minds. It is only possible to observe the students' learning, including their reflections on their own learning, indirectly, in the form of communicative constructions shared through classroom communication. An example would be when the students correctly/incorrectly translate a text, fail/succeed to solve a mathematical equation, or share their concerns about a theory. 
The learning process needs to be communicated in one way or another, in order for the teacher to observe it. Or, more correctly, the teacher can only observe a communicative contribution as an expression of the learning process (Luhmann, 2000, p. 152).

Second-order teaching is about teaching and learning that is explicitly communicated in a learning context. This is possible only if the learning process and the students' study strategies are addressed in the classroom, or, as Luhmann says, if they are thematized in the communication. From this perspective, second-order teaching may be seen as classroom communication about classroom communication. The purpose of this is to create study transparency through metacommunication (Thingholm, 2016), knowing that teaching and learning will never be fully transparent (Bengtsen \& Barnett, 2017), but rather an attempt to create transparency despite opaque complexity, in order to achieve relative transparency (Luhmann, 2000, p. 152).

\section{Context learning}

The concept of second-order teaching draws not only on Luhmann's concept of second-order observation, but also on Gregory Bateson's theory of logical categories of learning and communication (Bateson, 2000). When learners learn any given content, they simultaneously also learn about the context in which that content appears. This is based on learning studies, which show that test participants who have to repeatedly memorize senseless rhymes, learn not only the rhymes themselves, but also learn how to learn rhymes (Bateson, 2000; Keiding \& Laursen, 2005). The learners may or may not be conscious of the context of their learning, or the strategy that they use to learn the rhymes. This is comparable to second-order observation that observes how something has been observed. With respect to education, several themes are embodied in context learning: students learning about the type of given task or assignment, about academic norms and values, about the school and class as a specific learning environment in which to collaborate, and generally, learning about themselves as learners (Laursen, Keiding, \& Johansen, 2003).

As mentioned, context learning may take place without the students being conscious of how they learn and which strategies they make use of. In that case, context learning is only available for systematic reflection to a certain extent. To develop systematic reflection on study strategies or context learning has certain metacommunicative implications for teaching and learning. These implications are revealed below.

\section{Implications for teaching practice: metacommunication}

In an educational setting, and inspired by the concepts of metacognition and second-order teaching, the focus moves from "thinking about thinking" to "classroom communication about classroom communication." These concepts share a meta-perspective, but the first concept, thinking about thinking, refers to cognition and the psychological system, which is invisible for everybody else except the individual student. The second concept, communication about communication refers to the social system and the teaching taking place in the classroom as a joint effort. It is communication that the students, as opposed to cognition, can connect to and engage in with the teacher and each other. The purpose of metacommunication is to understand understanding by explicitly addressing not only the academic curriculum (the what dimension), the strategies for achieving the curriculum (the how dimension) and the purpose of introducing the curriculum (the why dimension), but also asking the students to reflect on and explain how they understand the curriculum, the strategies and the 
overall purpose. This kind of communication helps the students to observe their own learning process. They learn to do second-order observation in relation to their own learning and understanding of any given topic. They learn to observe how they have observed by identifying the distinction(s) behind their first observation and understanding. The teacher can facilitate this kind of meta-learning by asking the students to explicitly explain how they constructed meaning and how they relate to the curriculum. When facilitating this second-order learning, the teacher references the didactic dimension described above: What did you understand from the curriculum? (content dimension). Which strategies did you use? Could you have done anything differently? (method dimension). How is this meaningful to you? (purpose dimension).

Thereby, two parallel perspectives appear for the teacher to reflect on: 1) the teaching perspective and 2) the learning perspective. The first of these two perspectives involves reflection in relation to the classical didactic questions about "what-how-why": content, methods and purpose. This perspective is mainly concerned with the teaching dimension and how the teacher presents content. The second perspective concerns the learning perspective and involves reflection on how the students learn content. In other words, the learning dimension concerns the context and how it is possible to explore it. Moreover, the focus is not on the teacher's instruction, but on the students' learning processes (thinking and doing). From this perspective, the "what-how-why" questions are related to the learning process: What am I, as a learner, about to learn? How will I best learn this content? Why do I have to learn this content? Why is it important to me? (Thingholm and Keiding, 2018).

When teaching study strategies explicitly, the acquisition of relevant study strategies becomes more than just unconscious context learning, and is no longer something that students either do or do not manage. The responsibility for systematically acquiring relevant study strategies shifts from belonging to the individual student, to being something that pertains to classroom communication. Second-order teaching takes the form of a joint dialogue concerning what knowledge and skills students need to learn, and how and why they might learn these skills, but it also includes a 'looking back' perspective - an observation of how the students did understand the curriculum and an understanding of this understanding - which distinctions were underlying their understanding. Second-order teaching is metacommunication, and helps the students not only to understand the academic content, but also to understand the various study strategies used to understand the academic content. Put in theoretical terms, second-order teaching explicitly helps the students to observe how they have observed the academic content. In this way, the students become self-regulated learners who are able to control and regulate their own learning processes. Similar ideas are suggested in theories of self-regulated learning (Weinstein, Bråten, \& Andreassen, 2013).

This kind of metacommunication calls for a kind of dialogic pedagogy, in the sense that the teacher needs to engage in a dialogue with the students about how they study, about their strategies for acquiring new knowledge and skills, about their norms and values and about when they enjoy learning. It is equally important that the teacher introduces new study strategies, and that the students share their strategies, in order for them to acquire a repertoire of useful strategies. The Takeaway Teaching design is structured to support this kind of metacommunication in the classroom, and explicitly deals with which study strategies the students employ and how these strategies may be developed over time. 


\section{The design of Takeaway Teaching}

Above, we have unfolded the theoretical framework for the Takeaway Teaching design. Below, we describe the structure of the design and its themes. It consists of nine generic themes and 13 pre-designed mini-plans or scripts. The reason for choosing this pre-designed scripting design was to make it easy for university teachers to choose one (or more) relevant theme(s), read the content, adjust or redesign it and integrate it into the lesson plan. Each theme is developed by one or two subject developers who have a professional interest in the specific content. For example, the Literature Search theme is developed by a librarian who has professional experience of providing workshops for students on how to search and manage literature. Each theme is structured around a different number of elements and each element includes a number of activities. This structure recurs in each theme, in order to make the design consistent and easily accessible to the teachers. Figure 1 is an example of the structure of one of the themes; Academic Writing - Genre and writing process.

Figure 1. The structure of the theme Academic Writing - Genre and writing process

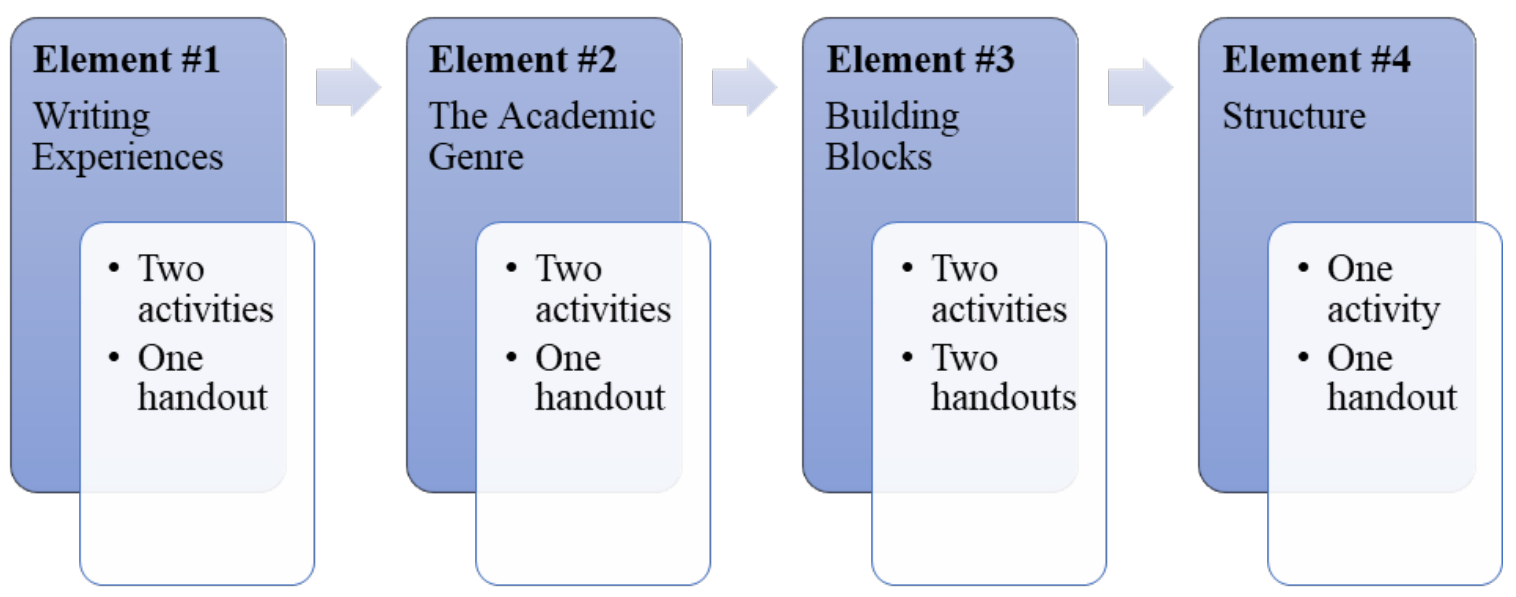

In the scripts, the activities are described in detail and the developers have included relevant didactic comments aimed at the teachers. If necessary, handouts for the students are included. Furthermore, for each element, the developer gives an estimate of how long it will take the students to complete the activities. The themes are all generic and may be directly implemented in the lesson plan, or they may be adjusted and redesigned by the teacher to better match the curriculum and the students. The design helps the teacher to facilitate metalearning not only by addressing strategies, for example academic reading and writing, but also by asking the students to think about how they usually reflect on strategies for academic reading and writing. According to the theoretical frame, students are asked to observe how they observe. The students have the chance to discuss and understand their current way of understanding academic reading and writing, an understanding that develops during their years of studying. Using the design makes it easier for the teacher to facilitate discussion about the students' different understandings of how and why to read and write.

When students are explicitly taught different generic strategies for studying they have the chance to relate to their own knowledge and use of strategies. An example of understanding academic writing could be the progression from understanding writing as a skill, learning to write, to understanding writing as a process of knowledge construction, writing to learn. The themes and the activities help to foster the understanding of this learning perspective. Exer- 
cises and handouts contribute with questions about the students' construction of knowledge in order to help them reflect on their own learning and develop academically. For example, they reflect on their own writing experiences and how academic writing is far more than a product; it is an ongoing cognitive process that creates new knowledge.

The themes are not constructed as online learning. It is not sufficient for the teacher to send the website's URL to the students or digitally conduct the activities without integrating them into the curriculum. In this sense, the design is not a "plug-and-play" activity. The design is available on an online learning resource, but the content is not an independent online course. Just as with any other teaching activity, the teacher needs to reflect on how to implement a Takeaway Teaching theme and its activities when planning the curriculum and the lessons. The activities must be facilitated by the teacher, but may be conducted by the students in class, or between classes as homework or group work.

The content of each theme is visible on the website and may be downloaded for use, but the content of each theme is also uploaded to the online study platform, Blackboard, in order to make it easy to implement the activities in the rest of the lesson plan. Whether the teacher chooses a printed or a digital version of the theme, they must read it thoroughly, possibly making changes here and there, removing unwanted activities, or adding supplementary activities and materials of their own. This redesign may be done by each individual teacher, but it may also be conducted by groups of teachers in the same discipline who want to try out the same theme. In this way, the teachers may develop more discipline-specific elements and activities if they wish to do so.

\section{Example of a redesign process}

In this section, we present an example of a redesign of a Takeaway Teaching theme in practice. In this example, the Literature Search theme was integrated into the Communication on the Internet course. This course is a part of the Information Studies master's programme at Aarhus University. The course is a 10-ECTS point course with 12 physical, face-to-face classroom sessions, various online exercises and one webinar. In the autumn of 2017, the class consisted of 18 students who, at the end of the course, handed in a short assignment using theories from the curriculum, combined with a case study of their own choosing and with additional literature. The course teacher and co-author of this paper, Anders Hjortskov Larsen, found the Literature Search theme appropriate, because he wanted to promote and support his students' skills in searching for relevant literature for their case study and assignments. Typically, the students would do the literature search on their own at home or maybe go to the library for help. With the pre-designed activities, Larsen found that it was possible to integrate the students' literature search into the lesson plan and facilitate the processes of literature search within the discipline at hand.

After requesting the Literature Search theme by e-mail, it was uploaded to the Blackboard course module. The Literature Search theme is based on activities, texts, tasks and videos showing the actual use of a database with truncation and other technical search strategies. This theme consists of three independent scripts: Inspirational Literature Search, Systematic Literature Search, and Reference Management. The first script focuses on a literature search as inspiration for identifying a problem statement or research question. The second script focuses on a systematic literature search in order to find relevant literature to enable discussion of the problem statement or research question. The third script is an introduction to the 
reference programme EndNote. In this case, the teacher chose to implement the first and second scripts into the curriculum, and omit the third script about EndNote.

This was the first broad decision of how to use the theme. Another general choice that led to a redesign of the given material involved the choice of digital media. In this case, the LMS Blackboard was not adequate for the way the course was being taught. Therefore, in order to fit the digital media setup of the course, the search results and discussions surrounding them were moved from Blackboard to a Facebook page and a WordPress blog, which were already integrated parts of the course.

The two scripts were timed to fit into the overall progression of the course, in order to motivate the students in the most effective way. The students handed in assignments on a weekly basis and the two scripts were timed to fit with the progression of these course assignments. Therefore, the first script was timed to fit with the third course assignment. Here, the students came up with new literature, and discussed it online in blog posts with their costudents and the teacher. Five weeks later, the weekly assignment was to further develop the students' research questions, and find additional literature that could support their analyses. Therefore, the second script was integrated. The requirement for this weekly assignment was to apply additional literature based on the new search strategies that they had learned. This requirement was aligned with the exam.

After the students had worked with the Takeaway Teaching theme, an evaluation was conducted as an in-class workshop, and later on in the official course evaluation, multiple questions were asked concerning the literature theme from the Takeaway Teaching design. The students discussed the focus on their study skills as something they already had worked with during their bachelor's programme, but they also mentioned that they found the various activities useful for the fulfilment of the weekly tasks. Some students mentioned the search strategies as something they knew about from earlier introductions in their studies, but had never used or reflected on.

Looking back at the redesign

Integrating the Takeaway Teaching theme opened up an opportunity to have a critical discussion about relevant literature and alternatives to the titles in the syllabus handed out by the teacher. In relation to the different kinds of knowledge; declarative, procedural and conditional, the class had a chance to reflect on and explain the three dimensions: what, how and why. The what dimension relates to what is known about the assignment at hand. Here, the students are asked to refer to relevant literature in order to support their academic argument in a text. The how dimension relates to knowledge about how to solve the task, in this case the ways in which relevant literature within the field are found, in other words which search strategies to use. The why dimension relates to knowledge about the purpose and the context, in this case the purpose of strengthening academic argumentation through references and to the learning taking place while searching for relevant literature, e.g. understanding that the syllabus is only a small part of a much greater academic field.

How did the re-design of the Takeaway Teaching theme support the teaching and learning within this example?

With regard to the what dimension, using the literature search theme did not change the demands of the assignment. The students were still asked to refer to relevant literature to support their argumentation just as before, but implementing the search activities increased 
the focus on literature search and made the students reflect on the search skills, which they had gradually developed during their studies over the years.

With regard to the how dimension, the integration of the theme lead to two new elements: Firstly, the students' literature search was explicitly integrated and related to the actual discipline, thereby reducing the problem of transfer from generic search courses at the library. Secondly, by presenting and trying out various search strategies in class the students gathered a greater repertoire of strategies as opposed to students doing the literature search on their own.

With regard to the why dimension, the integration of the theme made it possible for the teacher to be explicit about the purpose and the context of the literature search. This kind of discussion opened up an opportunity for the students to understand their own understanding of searching for literature - how to do it and why to do it. These kinds of meta-reflections do not happen just because a theme from the Takeaway Teaching design is implemented in the lesson plan, but the design does create an opportunity or space for the teacher and the students to allow these meta-reflections to take place. Larsen experienced that time was an important factor for creating these meta-reflections. Developing an awareness and use of search strategies as knowledge construction takes time and does not happen in one semester. Furthermore, developing metacommunication is not easy and it is an ongoing process for the teacher as well as for the students. Larsen found that implementing the Takeaway Teaching theme provided an opportunity for developing metacommunication, but it was still difficult and unfamiliar to him to have this kind of communication with the students. Using the same theme over time, this might change and metacommunication may gradually become more natural for the teacher.

Looking more closely at the example above, the teacher experienced an improved focus on discussions about searching for literature and a critical perspective on the literature of the syllabus. The process of searching for applicable literature in relation to the assignments within the research field supported the students' reflections and understanding of the academic field. Furthermore, it supported the students' general understanding about how to create new knowledge. In other words, the students learned to search for literature but to a certain extent, they also searched to learn and understand the literature of the field.

In this example, using the literature became a more active and reflective part of the students' learning process instead of being a demand from the teacher. The literature search thereby opened up learning processes within a concrete and real context instead of study skills and activities being disconnected from the actual curriculum. In this way, the literature search activities and strategies qualified the students' learning outcomes and their reflections about their knowledge acquisition throughout the course. This was visible in the way in which the students in their assignments referred to literature outside the syllabus. The students were more reflective and creative in their use of literature than previous students. Thereby, the students achieved a broader understanding of the subject knowledge of the course. By using the Takeaway Teaching theme and explicitly connecting search strategies to concrete assignments, the teacher found a greater alignment throughout the course. 


\section{Challenges and potentials of Takeaway Teaching}

To sum up, Takeaway Teaching inspires university teachers to explicitly address and develop study strategies as a part of their curricula. The design has potential with regard to two aspects. Firstly, the teachers reflect didactically on how to teach students to study a given discipline, and by implementing the Takeaway Teaching themes they make teaching and learning more transparent by addressing how students understand their understanding, and how developing study strategies is essential for knowledge construction. Secondly, from this explicitness the students gain by developing new study strategies and becoming more metaoriented with respect to their own learning processes.

Therefore, we argue that strengthening the teachers' didactic ability while developing the students' study skills improves the quality of teaching and learning. The design differs from ordinary textbooks by not presenting a certain academic discipline or content but by presenting useful strategies that support the learning of any given discipline. Takeaway Teaching is designed for university teaching and learning. However, the basic idea and design may also be useful at other educational levels.

Various aspects of Takeaway Teaching as a teaching design are challenging, and in the following section, we will highlight five challenges. Firstly, convincing teachers to try the new design has been challenging. Their hesitation is not related to the actual Takeaway Teaching design, or to the activities included in the themes, but mainly concerns the time needed to become familiar with the design, to spend time redesigning the activities and also to present it during lessons. Secondly, some teachers are unfamiliar with Blackboard, the university's LMS, and therefore find that integrating activities into their classrooms via Blackboard is an unmanageable task. We aim to resolve this by providing the described activities and ideas in various formats, such as print, new online formats and downloadable PDFs. Thirdly, it may be difficult for the teachers to adopt someone else's understanding and thinking about study strategies. The developer of a Takeaway Teaching theme, for example, Academic Reading, may have a different approach to reading scientific texts than the teacher who is going to apply the content and activities of the Takeaway Teaching theme. Fourthly, as we emphasized in the title of this paper, Takeaway Teaching is a design for redesign. This puts the teacher in charge of the content, the ways in which the study strategies are taught, and using metacommunication in the own classroom. The many redesigns of the actual content of Takeaway Teaching make it difficult to know precisely how the study strategies are being taught in different contexts and whether or not the second-order observations are fostered. Lastly, the Takeaway Teaching themes might limit the teachers' creativity if they believe that the themes and activities in the Takeaway Teaching design are conceived as the only way to teach study strategies, which is quite contrary to the intention of the design. Takeaway Teaching presents only some ways to teach study strategies, and is not an exhaustive collection of how study strategies might be taught in higher education.

Despite the possible challenges with using Takeaway Teaching, we do find that the Takeaway Teaching design is valuable and innovative because it manages to address the teacher and the students at the same time. Often, both generic teaching courses for teachers and generic study courses for students are detached from the curriculum, which may cause transfer problems related to their teaching and study practices. Takeaway Teaching integrates the development of practical teaching and study competence in the same lesson.

Furthermore, teachers and students have difficulty finding time to attend generic courses. 
Takeaway Teaching aims to address this problem, because it relates directly to teaching and study practices. As an alternative to generic courses that are detached from the classroom, the Takeaway Teaching design may reach and benefit a large number of teachers and students. During the first semester, in the autumn of 2017, Takeaway Teaching was used in 42 different courses at Aarhus University and reached 337 students. These numbers have been tracked from Blackboard, and more teachers may have used printed themes downloaded directly from the website. This number is far more than the teaching development centre of the faculty could provide generic courses for during one semester.

At the moment, further research related to the Takeaway Teaching design is being carried out, and the detailed results of a qualitative study that closely follows five university teachers and their students using the Takeaway Teaching design will be published later this year. Practical knowledge about using the design will be obtained, in order to qualify the ongoing design of Takeaway Teaching and its related themes.

\section{References}

Bateson, G. (2000), Steps to an ecology of mind. With a new foreword by Catherine Bateson. Chicago: Chicago University Press.

Bengtsen, S., \& Barnett, R. (2017), “Confronting the dark side of higher education”, Journal of Philosophy of Education, Vol. 51No. 1, pp. 114-131. Doi:10.1111/1467-9752.12190.

Coutinho, S. (2008), "Self-efficacy, metacognition, and performance", North American Journal of Psychology, Vol. 10 No. 1, pp. 165-172.

Flavell, J. H. (1979), “Metacognition and cognitive monitoring: A new area of cognitivedevelopmental inquiry", in: American Psychologist, Vol. 34, No, 10, pp. 5 Doi: http://psycnet.apa.org/doi/10.1037/0003-066X.34.10.906.

Frenkel, S. (2014), "Metacognitive components in learning to learn approaches" in: International Journal of Psychology: A Biopsychosocial Approach, Vol. 14 Doi: http://dx.doi.org/10.7220/2345-024X.14.5.

Hargrove, R. A., \& Nietfeld, J. L. (2015), “The impact of metacognitive instruction on creative problem solving", The Journal of Experimental Education, Vol. 83, No. 3, pp. 291-318. Doi:10.1080/00220973.2013.876604.

Harrison, G. M., \& Vallin, L. M. (2017), “Evaluating the metacognitive awareness inventory using empirical factor-structure evidence", Metacognition and Learning. Doi: 10.1007/s11409-017-9176-z.

Keiding, T. B., \& Laursen, E. (2005), Interaktion og Loering. Gregory Batesons bidrag: Unge Pædagoger.

Kuhn, D., \& Dean, J. D. (2004), "Metacognition: A bridge between cognitive psychology and educational practice", Theory Into Practice, Vol. 43, No. 4, pp. 268-273. Doi: 10.1207/s15430421tip4304_4.

Laursen, E., Keiding, T. B., \& Johansen, L. Ø. (2003), IT og Bateson: Et læringsteoretisk perspektiv. H. Mathiasen (Ed.), IT og loeringsperspektiver: Alinea. 
Luhmann, N. (2000), Sociale systemer. København: Hans Reitzels.

Luhmann, N. (2007), Indføring i systemteorien. København: Unge Pædagoger.

Pintrich, P. R. (2002), "The Role of metacognitive knowledge in learning, teaching, and assessing", Theory Into Practice, Vol. 41, No. 4, pp. 219-225. Doi:

10.1207/s15430421tip4104_3.

Schraw, G., Crippen, K. J., \& Hartley, K. (2006), "Promoting self-regulation in science education: Metacognition as part of a broader perspective on learning", Research in Science Education, Vol. 36, No. 1, 111-139. Doi: 10.1007/s11165-005-3917-8.

Thingholm, H. B. (2016), "Study Transparency through Meta-communication", paper presented at the SRHE International Conference on Research into Higher Education, Wales.

Thingholm, H. B., \& Keiding, T. B. (2018), "Second Order Teaching", Journal of the International Society for Teacher Education, Vol. 22, No. 1.

Veenman, M. V. J. (2015), "Teaching for metacognition”, International encyclopedia of the social \& behavioral sciences (2) (pp. 89-95). Doi: https://doi.org/10.1016/B978-0-08-0970868.92136-6.

Weinstein, C. E., Bråten, I., \& Andreassen, R. (2013), Læringsstrategier og selvreguleret læring: Teoretisk beskrivelse, kortlægning og undervisning. R. Andreassen, H. Bjerresgaard, I. Bråten, J. Hattie, M. Hermansen, T. N. Hopfenbeck, P. O. Kirkegard,

C. Madsen, H. Timperley, C. E. Weinstein, \& T. S. Wille, Feedback og vurdering for loering (pp. 145-174). Frederikshavn: Dafolo. 